Tamara Radjenovic ${ }^{1}$

Bojan Krstic ${ }^{2}$

University of Nis, Faculty of Economics
ORIGINAL SCIENTIFIC ARTICLE

DOI:10.5937/ekonomika1704013R

Received November, 15, 2017

Accepted: December, 11, 2017

\title{
INTELLECTUAL CAPITAL IN THE THEORY OF THE FIRM ${ }^{3}$
}

\begin{abstract}
Intellectual capital has an inevitable role in the value creation process and represents significant determinant of the firms' market success. In the contemporary circumstances, firms achieve and sustain their competitive advantages by mobilising and profitably exploiting intellectual resources. Therefore, the aim of this paper is to overview the evolutionary process of intellectual capital through theoretical examinations of different theories. The first notion of intellectual capital is connected with the resource-based view, then the dynamic capabilities and finally, the knowledgebased approach. The paper points toward increased importance of intellectual capital in contemporary circumstances.
\end{abstract}

Key words: intellectual capital, theory of a firm, resource-based view, dynamic capabilities, knowledge-based view

JEL classification: D83, L25, O34

\section{ИНТЕЛЕКТУАЛНИ КАПИТАЛ У ТЕОРИЈИ ФИРМЕ}

\begin{abstract}
Апстракт
Интелектуалникапиталиманеизоставнуулогуупрочесустварањавредности и представља значајну детерминанту тржишног успеха фирми. У савременим условима, фирме постижу и одржавају конкурентску предност мобилизовањем и профитабилним коришћењем интелектуалних ресурса. Отуда, ичиь овог рада је да прикаже еволуциони процес интелектуалног капитала кроз теоријско испитивање различитих теорија. Први помен интелектуалног капитала је повезан са ресурсним приступом, затим са динамичким способностима и на крају, са приступом заснованим на знану. Рад указује на повећани значај интелектуалног капитала у савременим условима.
\end{abstract}

Кључне речи: интелектуални капитал, теорија фирме, ресурсни приступ, динамичке способности, приступ заснован на знағу

\footnotetext{
${ }^{1}$ tamara.radjenovic@eknfak.ni.ac.rs

2bojan.krstic@eknfak.ni.ac.rs

${ }^{3}$ Acknowledgements: The paper is a result of research within project 179066 funded by the Ministry of Education, Science and Technological Development of the Republic of Serbia
} 


\section{Introduction}

One of the main research topics in the area of strategic management is to understand the source of sustainable competitive advantage of a firm. Starting from 1960s onwards, studies have mainly been structured on the basis of a single framework which implied that firms achieve sustainable competitive advantage by implementing strategies that use their own internal power (resources), through responding to the opportunities outside the firm, thereby neutralising external threats and avoiding internal weaknesses (Barney, 1991, p. 99).

Most of the research on sources of sustainable competitive advantage are focused on identifying opportunities and threats (Porter, 1980; 1985), describing the strengths and weaknesses (Penrose, 1959; Stinchcombe, 1965), or analysing their connection with the selected strategies. Although certain attention is paid to the internal analysis of organizational strengths and weaknesses, the primary focus of research in this period was directed towards the external analysis of opportunities and threats in a competitive environment (Barney, 1991, p. 100), and researchers aimed to describe the favourable background conditions that lead to achieving high business performance (Porter, 1980; 1985). Thus, for example, Porter's five forces model (Porter, 1980) identifies the characteristics of the attractive industries, hence suggesting that opportunities will be greater, and threats smaller in such industries.

Until the 1980s, mainstream managerial theories focused on the external environment of a firm (i.e. industry structure) as a basis for understanding the competitive advantages (Roos $\&$ Roos, 1997, p. 414). Within the strategic analysis of the external environment impact on the competitive position of a firm, little attention was paid to the influence of unique, specific characteristics of a firm on its competitive position. Specifically, these models of competitive advantages were based on two simple assumptions: 1) firms within the same industry (or strategic group) are identical in terms of strategically important resources that control and strategies that follow (Scherer, 1970; Porter, 1981; Rumelt, 1997); 2) in the case of the occurrence of heterogeneous resources in a particular industry or group, this heterogeneity will be short-term, because the resources that firms use in implementing their strategies are very mobile, i.e. they can be bought and sold in the production factor market (Barney, 1986; Hirshleifer, Glazer, \& Hirshleifer, 2005). In other words, according to neoclassical economic theory, it was believed that resources are identically distributed within the industry and that are easily accessible by competing firms. Accordingly, the role of management was to come up with new, better ways to combine products and markets considering the bargaining power of suppliers and buyers, entry barriers and potential substitute technologies and/or product (Roos \& Roos, 1997, p. 414). The key message of Porter's theory of competitive advantage was that the environment is more important for creating competitive advantage than actions inside the firm (Roos \& Roos, 1997).

However, in the 1980s, this view was replaced with a new perspective - the resourcebased theory of the firm. Based on some elements raised by Penrose in her work in 1950s (Penrose, 1959), the proponents of this theory believe that the competitive advantage cannot be only attained through different combinations of products and markets in a particular industry, but through the differences that exist in the combination of the different resources in the firm, where the resources are considered as strength or weakness of a certain firm (Wernerfelt, 1984, p. 172).

By further elaboration of these ideas, Barney (Barney, 1991) has developed four criteria for determining what kind of resources provide a sustainable competitive advantage: 
1) value for the consumer; 2) rareness in comparison to the competition; 3 . inability to imitate; and 4. sustainability. The only resource that seems to be able to meet such set of criteria is "knowledge": invisible assets (Itami, 1987), the absorptive capacity (Cohen \& Levinthal, 1990), core competencies (Prahalad \& Hamel, 1990), strategic assets (Amit \& Schoemaker, 1993), organizational skills (Zander \& Kogut, 1995), intangible resources (Hall, 1992), organizational memory (Walsh \& Ungson, 1991) and so on. For example, Itami (1987) considers the invisible assets as the most important resources in the production process, which are based on a free exchange of information, both within the company, as well as with the environment.

The next logical step of the researchers who tried to understand the nature of knowledge was the categorization of knowledge. Although there have been various proposals such as: embedded knowledge, encoded knowledge, procedural knowledge (Blackler, 1995; Lam, 2000), the most used distinction is on implicit and explicit knowledge (Polanyi, 1966). Further, there is a distinction in terms of individual and organizational explicit and implicit knowledge (Lam, 2000, p. 491; Krstić, 2014, p. 104).

Based on all this, it can be pointed out that research in the field of strategic management shifted its focus from studying the external environment or industry structure to the study of heterogeneous resources within the firm or its capabilities, competencies and knowledge as a source of sustainable competitive advantage. Therefore, the aim of the paper is to overview the evolutionary process of intellectual capital through the lens of various theories.

The paper is structured as follows. The introduction gives the brief overview of the subject of the paper. The first section is devoted to the intellectual capital theory. Afterwards, the resource-based theory, the dynamic capabilities theory, and the knowledge-based theory are overviewed. At the end, the conclusion sums up the main findings and points out the importance of intellectual capital within the different theoretical stands.

\section{The Theory of Intellectual Capital}

The theory of intellectual capital draws its roots from both management and macroeconomic theory. The intellectual capital theory is a new prominent theory which is based on the premise that, in the contemporary circumstances, intangible assets not disclosed in the balance sheet are very important for the firm's operations, since they can significantly increase the value of assets or the market value of the firm (Kolaković, 2003, p. 925). This theory is based on the belief that the wealth of the firm depends on the human, structural and relational capital, and value is created by converting one form of capital into another form (Kolaković, 2003, p. 925).

The origins of the concept of intellectual capital in the 20th century are associated with Taylor and his book "The Principles of Scientific Management” from 1911, in which he writes about knowledge, experience and skills of employees (Taylor, 1911). Sometime later, the idea of intellectual capital has also been found in the works of Chamberlin (1933) and Robinson (1933), who emphasized that firm's capabilities, technical knowhow, trademarks, brands, patents, etc. are key to the business success.

Further progress in the economic theory was done by Schumpeter (1934) "who emphasised the recombination of knowledge as a necessary precondition for the appearance of new innovative products" (Rađenović \& Krstić, 2017b, p. 191). Elements 
of the theory of intellectual capital can be found in Simon's "Administrative behaviour", who believed that intellectual capital was limited only by a bounded rationality of employees in a firm, i.e. human cognitive capacities (Kolaković, 2003, p. 928).

A significant contribution to the development of the theory of intellectual capital gives Penrose in her "The theory of the growth of the firm" from 1959, in which she points out that the unique intangible intellectual resources and unique capabilities of the firm are the key determinants of business performance (Krstić, 2014). At the same time, she emphasizes the importance of management in using available internal resources, i.e. their experience and skills in converting resources into products that will meet the needs of the consumers, thus contributing to the exploitation of market opportunities. Otherwise, the term intellectual capital is originally linked to Machlup (1962), who coined it to highlight the importance of knowledge for growth and development of firms and national economies (Rađenović \& Krstić, 2017a).

A special contribution to the development of the theory of intellectual capital gave Polanyi (1966) by differentiating the explicit and implicit knowledge and emphasizing that the success of a firm could be achieved only through their interaction. Inevitable place in the development of the concept of intellectual capital certainly belongs to Romer (Romer, 1990), who made a significant contribution to the endogenous growth theory.

In addition to Romer, many other authors, who independently studied intangible assets, are important for the emergence of the concept of intellectual capital. Namely, there are three different schools which in their own way contributed to the development of the theory of intellectual capital (Kolaković, 2003, pp. 930-931):

- The "Japanese school" led by Itami, who in the 1980s studied the contribution of invisible assets in the case of Japanese firms, and stressed the importance of intangible assets for the modern firms thus prompting the significant research of intangible assets worldwide. Within this school it is important to mention Nonaka and Takeuchi (Nonaka \& Takeuchi, 1995) who dealt with the issue of knowledge management and described how Japanese firms innovate their business by implementing and disseminating explicit and implicit knowledge, thereby highlighting that organizational knowledge cannot be created by firms, but only individuals who work in them.

- The resource-based theory, which starting from the positions of Penrose (1959), Rubin (1973), Wernerfelt (1984), Barney (1991) and Rumelt (1997), put an emphasis on resource efficiency, with special attention to the management of intangible intellectual resources, and strategies for the use of existing resources. Also within this group following contribution could be added:

o Nelson and Winter (1982), in the context of evolutionary theory, who viewed the firm as a "warehouse" of knowledge, with special emphasis on organizational routines that allow the interaction of explicit and implicit knowledge;

o Prahalad and Hamel (1990), in the context of core competence theory, who, as the core competencies of a firm, viewed intellectual property, know-how and distribution network;

o Teece (1986), who looked at technological innovation as a source of value and showed the detailed steps necessary for the commercialization 
of knowledge through innovations.

- The study of human capital, which began back in 1776 with the known work of Adam Smith "Wealth of Nations" and ends in the 1960s when the theoretical and empirical basis of human capital, as an integral part of intellectual capital, were designed (Sweetland, 1996). In fact, Smith wrote in detail about the importance of knowledge and skills of employees in the production process, especially emphasizing that learning and education represent investments in people (Nerdrum \& Erikson, 2001, стр. 128). Almost a century later, in 1890, Marshall argued that the most valuable capital is the one invested in people, but none of them had used the term human capital. A significant contribution to the formulation of the modern theory of the human capital was given by Mincer (1958; 1962), Schultz (1961) and Becker (1962) who viewed human capital as an independent category of capital, which analogous to conventional capital possesses economic and production characteristics. Becker (2009) even believes that people are the most valuable resource that increases business opportunities.

However, the development of the theory of intellectual capital has in recent years been guided by the ideas and thoughts of influential authors and practitioners, including Kaplan and Norton (1992), Sveiby (1997), Stewart (1997), Edvinsson and Malone (1997), Brooking (1997) and many others (Harris, 2000; Viedma Marti, 2007). The increased difference between the market and book value of the firms encouraged the academic and business community to consider the concept of intellectual capital as a key determinant in the process of creating value for shareholders, managers and society as a whole. It is the contributions of influential practitioners that have laid the foundations of the way intangible factors determine the success of the firm, i.e. the foundations of the "standard theory of intellectual capital" (Andriessen, 2001). However, the huge interest of researchers and practitioners to study the intellectual capital, resulted in numerous improvements to the standard theory of intellectual capital and its further development in the future (Harris, 2000; Andriessen, 2001; Viedma Marti, 2007).

Hence, Harris differentiates (2000, pp. 28-33):

- The static theory of intellectual capital, based on which the corporate value is not derived directly from any of the components of intellectual capital, but from their interaction, whereby the nonexistence of any component prevents a firm to use the potential of transforming its intellectual capital into the corporate value. The basic concept of the static theory of intellectual capital is very simple - it is based on the wealth of knowledge embedded in individuals and organizations, and the need to mutually connect these systems in order to improve performance.

- The dynamic theory of intellectual capital, based on which it is necessary to completely eliminate the relational capital from the structure of the intellectual capital, and to replace structural capital with the theory of the system. By accessing intellectual capital through the theory of the system, rather than structural capital, the organization is able to recognize its connections. The theory of the system connects individuals to the processes, and in turn with the organization, thus enabling the verification of compliance that every individual and process in the organization is associated with the respective strategic plans and business objectives of 
the organization. Given that the intellectual capital environment promotes the diffusion of knowledge in order to improve performance, information and feedback from consumers should always be available and visible in the organization in which a system of intellectual capital is set up. Hence, in an intellectual capital environment, competitive advantage creates the organizational knowledge and systems designed to access that knowledge. Therefore, the dynamic theory is based on the constant exchange of knowledge between the human capital and designed systems.

\section{The Resource-based Theory of The Firm}

The resource-based theory has taken a prominent place in economic theory in the late 20th century, when the focus of strategic research of the sources of competitive advantage shifted from industry, i.e. external environment to the specific characteristics of the organization i.e. internal environment (Spanos \& Lioukas, 2001). The central premise of the resource approach is that the competitiveness of an organization is based on its resources and capabilities (Peteraf \& Bergen, 2003). The development of the resource-based theory of the firm is primarily focused on establishing a connection between resources and competitiveness, as well as examining the impact of these connections on creating sustainable competitive advantage and improving firm's performances (Krstić \& Sekulić, 2016, p. 355). The resource-based theory of the firm observes a strategy as an instrument for the alignment of resources and capabilities of a firm with the requirements of the external environment (Rađenović \& Krstić, 2017a).

The resource-based theory starts with two assumptions in the analysis of the sources of competitive advantage (Barney, 1991, p. 101): First, firms within a particular industry or group can be heterogeneous in terms of strategic resources they control; second, these resources need not be perfectly mobile between firms, and thus heterogeneity can be long-lasting. The resource model of the firm examines the implications of these two assumptions in the analysis of the sources of sustainable competitive advantage. Therefore, the heterogeneity of resources determines the heterogeneity between firms. Namely, firms possess different resources and do not use them equally successful, and as a result different firms have different efficiency performances. The resources of a firm include all assets, capabilities, organizational processes, characteristics of a firm, information, knowledge, etc., which it controls and which enable it to create and implement strategies to improve efficiency and effectiveness (Daft, 2010). It can be said that internal resources are the strength of the firm, which it uses for defining and implementing strategies.

The resources of a firm can be classified into three major categories (Barney, 1991, p. 101):

- Material resources (physical capital), related to technology used in a firm, plant and equipment, geographical location, and access to raw materials;

- Human resources (human capital), related to the training, experience, judgment, intelligence, relationships and insight of the individual managers and employees in a firm; and

- Organizational resources (organizational capital), related to the formal structure of reporting in a firm, formal and informal planning, controlling 
and coordinating systems, as well as informal relationships between groups within the same firm, and with other external firms.

Of course, not all aspects of the physical, human and organizational capital of a firm are strategically significant resources to create and sustain competitive advantages - some may pose obstacles to the implementation of valuable strategies, some can lead to reduced efficiency and effectiveness of implemented strategies, and some have no influence the strategic processes of a firm. In this sense, in terms of the resource-based theory of the firm, only those physical, human and organizational resources are important which enable firms to design and implement strategies that improve their efficiency and effectiveness (Wernerfelt, 1984).

A firm has a competitive advantage when implements a strategy of value creation that is not at the same time applied by any current or potential competitors, and it achieves a sustainable competitive advantage when apart from this criteria, the competitors are not able to replicate the advantages of this strategy (Barney, 1991, p. 102).

Due to the fact that a firm is a set of different resources that affect the performance of a particular firm through interaction with other resources, and the direction of this causal link is vague, it is difficult to determine how individual resources contribute to the success of a firm, without taking into account the interdependence with other resources (Lippman \& Rumelt, 1982; Dierickx \& Cool, 1989). Ambiguity, i.e. the uncertainty in terms of the factors which contribute to the superior or inferior performance of a firm significantly affect the possibility of imitation and the mobility of factors, considering that these factors cannot be replicated or moved if they are unknown. In addition to uncertainty of factors affecting the performance of a firm, even more important is the uniqueness of the resources used, which also prevents imitation by competitors (Lippman \& Rumelt, 1982, p. 420). According to the resource-based theory of the firm, resources must have certain characteristics in order to provide a competitive advantage (Barney, 1991, p. 105; King \& Zeithaml, 2001, p. 75):

- Valuable - to provide strategic value of a firm by enabling management to exploit opportunities and eliminate threats from the environment;

- $\quad$ Rare - difficult or impossible to find with existing or potential competitors;

- Irreplaceable - impossible to substitute by alternative resources; and

- Inimitable - that cannot be imitated by competitors.

Lin (2013, pp. 54-55) believes that intellectual capital, as a valuable knowledge resource, possesses these characteristics, i.e. intellectual capital is a valuable, rare, unique and difficult to imitate, can be communicated to others and its components are identifiable and comprehensive. With the above characteristics, intellectual capital can be turned into a competitive advantage of a firm.

Since intangible assets cannot usually be easily seen, felt or described, for decision makers is very important that, the intellectual capital through its basic components, can be transmitted to the key stakeholders. In addition, the best way to capitalize the value of intellectual resources is through the realisation of appropriate business performances of a firm. Therefore, the resources and capabilities of a firm should be used effectively to achieve a better competitive potential and intellectual capital is a visible result of applied management practices, techniques and tools (Rađenović \& Krstić, 2017a).

The basic elements of the resource-based theory can be summarized as follows (Kay, 1996, pp. 33-34):

- A firm is essentially a collection or set of capabilities;

- The effectiveness of a firm depends on the coordination between these capabilities and markets it covers;

- Growth and the appropriate limits of a firm are limited by its capabilities; 
- Some of these capabilities can be purchased or created and are available to all firms;

- While others cannot be or may but very difficult to replicate by other firms, and this determines the competitive advantage;

- Such capabilities generally cannot be replicated because they are the product of its history or because of the uncertainty of its nature (even within the same firm).

Development of the resource-based theory differentiates two directions: static, which is focused on the static aspects of resource analysis by understanding the way in which a particular resource contributes to creating and sustaining a competitive advantage; and dynamic, which seeks to connect the firm development with the process of improving the effects of the resource usage (Foss, 1997, p. 348).

What can be stated as a significant disadvantage of the resource-based theory is the fact that it does not link the analysis of the firm development with the analysis of the sustainable competitive advantage, but rather treats them separately (Krstić \& Sekulić, 2016). For this reason, the process of the use of resources should be directed towards those activities that can have a positive impact on the growth and development of the firm, and through greater creativity in choosing, combining and using resources to achieve the greatest possible synergy effects and desirable competitive advantage.

\section{The Theory of Dynamic Capabilities}

The relationship between the knowledge component and the resources component in the produced outputs has changed significantly, thus contributing to the change of the source of competitive advantage. In the past, advantages were based on the market dominance or organization of the process of mass production, while in modern circumstances competitive advantage lies in the brand and reputation, patents and standards, relationships with employees, suppliers and customers. Those sources of competitive advantage represent various forms of intellectual capital, which could create huge differences between the book value of a firm and its market value, which also encompass a value of the undisclosed intellectual capital (Hunter, 2002, p. 4).

Competitive advantage in business is essentially based on a variety of unique competencies, i.e. capabilities to do things others cannot. What happened in the 20th century is that the sources of these different, unique competencies change on the way to the knowledge economy. In the knowledge economy, for successful firms is not enough to just hire talented people, but they need to add value to them, whereby it is necessary to distinguish between the contributions of the organization and the contributions of individuals (Kay, 2000, p. 48). While intellectual resources are embedded in the experience and expertise of individuals, firms provide physical and social resources, as well as the structure of resource allocation, that allows the transformation of knowledge i.e. intellectual resources in competencies (Teece, 2000, p. 12). The way in which these competencies and intellectual resources are configured and employed will greatly affect the competitive position and the commercial success of a firm.

Given that the current assets of a firm are mainly intangible, it is unclear which of them belong to the firm, and which part is embedded in employees. In addition, superior technology by itself is not sufficient for creating and sustaining a competitive advantage, but cognitive and managerial skills are also necessary to identify and combine relevant complementary assets for encouraging business (Teece, 2000, p. 8). 
In a constantly changing environment, what provides the basis for creating competitive advantages is the ability to recognize and exploit opportunities, i.e. dynamic capabilities (Teece, 2000, p. 8). Dynamic capabilities represent the abilities of a firm to integrate, create and reconfigure internal and external competencies to respond to extremely volatile environment (Teece, Pisano, \& Shuen, 1997, p. 516). Dynamic capabilities are to be found in firms that are mainly entrepreneurial oriented, with a horizontal organizational structure, clear vision, high incentives to managers/employees and a high degree of autonomy in order to ensure rapid response to changes in the dynamic environment (Teece, 2000, p. 8).

Resource performances and dynamic capabilities of a firm set the activities of imitation and experimentation with resources, as well as the assessment of the costs of these activities, and lead to a new structure of resources which, as a result of learning by imitation and experimentation, determines a future production quantity, but also product and process innovations (Zott, 2003).

In this manner, a firm can be thought of as a value chain which value is created by transformation of the inputs to the outputs, that is, as a set of separate, but interrelated strategically important economic activities in the design, production, delivery and sale of products and services, whose better and more cost-effective performance compared to competitors leads to the competitive advantage (Viedma Marti \& Cabrita, 2012, p. 77). This practically means that the competitive advantage is the result of the firm's capabilities to accomplish the above mentioned activities at a lower cost in comparison to the competitors, or in a unique way which enables a firm to determine a higher cost, wherein the structure of the activity, and the way in which they are set, are determined by the strategy of the firm (Viedma Marti \& Cabrita, 2012, p. 78).

\section{The Knowledge-based Theory}

A sustainable competitive advantage is based on the knowledge of a firm as one of the main components of intellectual capital (Hunter, 2002). Competitive capability is largely dependent on the capability of an organization to develop, differentiate, adopt and disseminate its knowledge base. Knowledge in an organization is a resource on which a firm can build and maintain the core competencies that, if being adopted, enable it to survive and prosper in a competitive world (Hunter, 2002, p. 8). As proponents of the theory of knowledge stand out Leonard-Barton (1992), Grant (1996), Spender (1996) and Liebeskind (1996).

The knowledge-based theory puts emphasis on knowledge as a resource which is difficult to imitate, which differentiates and creates a competitive advantage (Leonard-Barton, 1992). The knowledge-based view of the firm distinguishes four dimensions of set of skills: knowledge and skills of employees, technical systems, management systems and values and norms associated with different types of personalized and embedded knowledge, as well as, the processes of knowledge creation and control. In addition, Grant highlights the fact that knowledge is "the critical input in the production and the primary source of value" (Grant, 1996, p. 112). According to Spender (1996) organization is seen as a lasting alliance between independent entities that create knowledge, regardless of whether they are individuals, teams, or other organizations, with the material resources subordinated to the provided services. This suggests that in the constantly changing environment, the most successful firms are those 
which produce original knowledge, spread it within the organization and quickly transform it into innovative products.

Liebeskind (1996) believes that firms as institutions have a key role in creating and sustaining a competitive advantage by protecting useful and valuable knowledge. In particular, given that the intellectual property rights are insufficiently regulated, but also expensive to propose and implement, firms are able to use a range of organizational arrangements that are not available on the market to protect the value of knowledge. Hence, firms can in many ways prevent the expropriation of knowledge, and reduce the visibility of knowledge and its products, thus protecting them from imitation. In this way a firm can achieve the "possession rights" which are also valuable, if not more valuable, than the limited property rights of knowledge required by the law (Liebeskind, 1996, p. 94). Therefore, the uniqueness, which is the key to competitive advantage, actually depend on the adoption of the various protective arrangements by firms.

If the core knowledge is a main strategic asset of an organization, then its main tasks are to improve the existing knowledge and to create a new core knowledge (Viedma Marti, 2007). At the same time, creation and improvement of core knowledge require the capabilities of organizational learning, including the corresponding structure of learning and information systems, where the valuable knowledge can only be obtained through a systematic and repeated comparison to the processes and core competencies of "world class" competitors in the same business segment.

\section{Conclusion}

Starting from 1980s onwards, the intellectual capital has become the most important determinant of growth and competitiveness. In the knowledge economy, knowledge resources are the main source for creating and sustaining competitive advantage of a firm. Namely, technological revolution and spreading out of knowledge-based activities have altered the way firms organize their business. Instead of using traditional production factors, their emphasis has been put on the knowledge resources and capabilities of their efficient usage.

In contemporary circumstances competitive advantage of firms is not derived from their market positions, but from the difficulty of copying, i.e. imitating of intellectual assets and the way in which they are used. Since it is not always possible to attain or imitate resources, attention must be focused towards the internal organisation of the firm to find the real source of sustainable differences in resources, i.e. the internal organisation of the firm is as important as its environment. From the aspect of the strategic management literature, which points out the multi-dimensional characteristics of firm's resources, i.e. their various combinations, intellectual capital represents a multi-dimensional portfolio of resources (Lin, 2013, p. 55). Intellectual capital represents a distinctive and comprehensive combination of resources, as it components include employees and leaders, structures and systems, and social relations.

Because of this, the theory of dynamic capabilities considers that efficient usage of resources is not sufficient for the success of a firm, but is necessary certain functionally specific capabilities (in production, purchasing, sales, research and development, etc.) (Krstić, 2007, p. 349). In other words, the resources themselves cannot contribute to the sustainable competitive advantages of a firm, but this role is attributed to the firm's capabilities, which are 
developed through complex interactions with resources, and which allow the firm to use its available resources in combination with the specific information and organizational processes (Amit \& Schoemaker, 1993).

Looking at the research on the intellectual capital it is possible to differentiate several stages in the development (Chaminade \& Vang, 2007, pp. 128-129; Krstić, 2014, pp. 8-9): The first stage, until the mid-1980s, in which the intellectual resources, which are rare, durable, hard to imitate, and especially knowledge, seen as an important determinant for creating and maintaining competitive advantage and it was necessary to manage them; The second stage, from the mid-1980s to the middle of the first decade of the 21 st century, in which the researchers were mainly concerned with the problems of conceptualization and measurement of intellectual capital, as well as reporting on intellectual capital with the aim to manage it efficiently; The third stage, from the middle of the first decade of the 21 st century, in which the attention of researchers is mainly occupied with issues of effective usage of intellectual capital in the management of business systems in order to accomplish greater economic efficiency.

In order for a firm in contemporary circumstances to maximize its strategic advantages in the long term, it is necessary to focus on its own internal resources and key sources of intellectual or supplementary activities that represent its core competencies i.e. capabilities which create and maintain significant long-term differences in the minds of consumers. In this sense, the strategy of a firm needs to develop internally the best capabilities or competencies such as: database, skills, organizational and technical competencies in which a firm already has considerable expertise, and which will enable the achievement of maximum value for key stakeholders, as well as to focus externally on those networks of suppliers that perform activities that must be bought in the market. In this way, dynamic capabilities reflect the firm's ability to achieve unique and innovative forms of competitive advantage given the firm's current market position and previous practices. As a result, firms compete with each other based on core competencies and knowledge.

\section{References}

Amit, R., \& Schoemaker, P. J. (1993). Strategic Assets and Organizational Rent. Strategic Management Journal, 14(1), 33-46. doi:10.1002/smj.4250140105

Andriessen, D. (2001). Weightless Wealth: Four Modifications to Standard IC Theory. Journal of Intellectual Capital, 2(3), 201-214. doi:10.1108/14691930110399941

Barney, J. B. (1986). Strategic Factor Markets: Expectations, Luck, and Business Strategy. Management Science, 32(10), 1231-1241. Retrieved from http://www. jstor.org/stable/2631697

Barney, J. B. (1991). Firm Resources and Sustained Competitive Advantage. Journal of Management, 17(1), 99-120.

Becker, G. S. (1962). Investment in Human Capital: A Theoretical Analysis. Journal of Political Economy, 70(2, Part 2: Investment in Human Beings), 9-49.

Becker, G. S. (2009). Human Capital: A Theoretical and Empirical Analysis, with Special Reference to Education (3rd ed.). Chicago: The University of Chicago Press. 
Blackler, F. (1995). Knowledge, Knowledge Work and Organizations: An Overview and Interpretation. Organization Studies, 16(6), 1021-1046. doi:10.1177/017084069501600605

Brooking, A. (1997). The Management of Intellectual Capital. Long Range Planning, 30(3), 364-365. doi:10.1016/S0024-6301(97)80911-9

Chamberlin, E. (1933). The Theory of Monopolistic Competition. Cambridge: Harvard University Press.

Chaminade, C., \& Vang, J. (2007). Strategic Change in Mature Sectors: When and How is Intellectual Capital Relevant? In C. Chaminade, \& B. Catasús (Eds.), Intellectual Capital Revisited: Paradoxes in the Knowledge Intensive Organization (pp. 124-145). Cheltenham, UK: Edward Elgar Publishing.

Cohen, W. M., \& Levinthal, D. A. (1990). Absorptive Capacity: A New Perspective on Learning and Innovation. Administrative Science Quarterly (Special Issue: Technology, Organiyations, and Innovation), 35(1), 128-152. Retrieved from http://www.jstor.org/stable/2393553

Daft, R. L. (2010). Organization Theory and Design (10th ed.). Mason, OH: SouthWestern Cengage Learning.

Dierickx, I., \& Cool, K. (1989). Asset Stock Accumulation and Sustainability of Competitive Advantage. Management Science, 35(12), 1504-1511. doi:10.1287/ mnsc.35.12.1504

Edvinsson, L., \& Malone, M. (1997). Intellectual Capital: Realising Your Company's True Value by Finding Its Hidden Brainpower. New York: Harper Collins Publishers Ins.

Foss, N. (1997). Resources and Strategy: Problems, Open Issues and Ways Ahead. In N. Foss, Resources Firms and Strategies - A Reader in the Resource-Based Perspective (pp. 346-365). Oxford: Oxford University Press.

Grant, R. M. (1996). Toward a Knowledge-Based Theory of the Firm. Strategic Management Journal, 17(S2), 109-122. doi:10.1002/smj.4250171110

Hall, R. (1992). The Strategic Analysis of Intangible Resources. Strategic Management Journal, 13(2), 135-144. doi:10.1002/smj.4250130205

Harris, L. (2000). A Theory of Intellectual Capital. Advances in Developing Human Resources, 2(1), 22-37. doi:10.1177/152342230000200104

Hirshleifer, J., Glazer, A., \& Hirshleifer, D. (2005). Price Theory and Applications: Decisions, Markets, and Information (7th ed.). Cambridge: Cambridge University Press.

Hunter, L. (2002). Intellectual Capital: Accumulation and Appropriation. Melbourne Institute Working Paper No. 22/02. Melbourne, Australia: Melbourne Institute of Applied Economic and Social Research, The University of Melbourne. Retrieved from https://www.melbourneinstitute.com/downloads/working_paper_series/ wp2002n22.pdf

Itami, H. (1987). Mobilizing Invisible Assets. Cambridge, MA: Harvard Business Press. 
Kaplan, R. S., \& Norton, D. P. (1992). The Balanced Scorecard - Measures that Drive Performance. Harvard Business Review, 70(1), 71-79.

Kay, J. (1996). The Business of Economics. Oxford: Oxford University Press.

Kay, J. (2000). Knowledge: The 21st Century Asset. RSA Journal, 148(5495), 46-49. Retrieved from http://www.jstor.org/stable/41378998

King, A. W., \& Zeithaml, C. P. (2001). Competencies and Firm Performance: Examining the Causal Ambiguity Paradox. Strategic Management Journal, 22(1), 75-99. doi:10.1002/1097-0266(200101)22:1<75::AID-SMJ145>3.0.CO;2-I

Kolaković, M. (2003). Teorija intelektualnog kapitala. Ekonomski pregled, 54(11-12), 925-944.

Krstić, B. (2007). Resursi i konkurentska prednost preduzeća. In Z. Aranđelović, Regionalni razvoj i demografski tokovi zemalja Jugoistočne Evrope (pp. 347356). Niš: Ekonomski fakultet Univerziteta u Nišu.

Krstić, B. (2014). Upravljanje intelektualnim kapitalom preduzeća. Niš: Ekonomski fakultet Univerziteta u Nišu.

Krstić, B., \& Sekulić, V. (2016). Determinante resursno baziranog pristupa unapređenju strategije, konkurentnosti i performansi preduzeća. In J. Đurović Todorović, \& M. Radosavljević, Konkurentnost i održivi razvoj privrede Republike Srbije (pp. 354-369). Niš: Ekonomski fakultet Univerziteta u Nišu.

Lam, A. (2000). Tacit Knowledge, Organizational Learning and Societal Institutions: An Integrated Framework. Organization Studies, 21(3), 487-513. doi:10.1177/0170840600213001

Leonard-Barton, D. (1992). Core Capabilities and Core Rigidities: A Paradox in Managing New Product Development. Strategic Management Journal, 13(S1), 111-125. doi:10.1002/smj.4250131009

Liebeskind, J. P. (1996). Knowledge, Strategy, and the Theory of the Firm. Strategic Management Journal, 17(S2), 93-107. doi:10.1002/smj.4250171109

Lin, C. Y.-Y. (2013). Intellectual Capital Explains a Country's Resilience to Financial Crisis: A Resource Based View. In P. O. de Pablos, R. Tennyson, \& J. Yhao, Intellectual Capital Strategy Management for Knowledge-Based Organizations (pp. 52-75). Hershey: Business Science Reference (IGI Global). doi:10.4018/9781-4666-3655-2.ch005

Lippman, S. A., \& Rumelt, R. P. (1982). Uncertain Imitability: An Analysis of Interfirm Differences in Efficiency under Competition. Bell Journal of Economics, 13(2), 418-438. Retrieved from http://www.jstor.org/stable/3003464

Machlup, F. (1962). The Production and Distribution of Knowledge in the United States. Princeton, New Jersey: Princeton University Press.

Mincer, J. (1958). Investment in Human Capital and Personal Income Distribution. Journal of Political Economy, 66(4), 281-302.

Mincer, J. (1962). On-the-Job Training: Costs, Returns, and Some Implications. Journal of Political Economy, 70(5, Part 2: Investment in Human Beings), 50-79.

Nelson, R. R., \& Winter, S. G. (1982). An Evolutionary Theory of Economic Change. Cambridge, MA: The Belknap Press of Harvard University Press. 
Nerdrum, L., \& Erikson, T. (2001). Intellectual Capital: A Human Capital Perspective. Journal of Intellectual Capital, 2(2), 127-135. doi:10.1108/14691930110385919

Nonaka, I., \& Takeuchi, H. (1995). The Knowledge Creating Company. New York: Oxford University Press.

Penrose, E. (1959). The Theory of the Growth of the Firm. Oxford: Oxford University Press.

Peteraf, M., \& Bergen, M. (2003). Scanning dynamic Competitive Landscapes: A Market-Based and Resource-Based Framework. Strategic Management Journal, 24, 1027-1041. doi:10.1002/smj.325

Polanyi, M. (1966). The Tacit Dimension. New York: Anchor Books.

Porter, M. E. (1980). Competitive Strategy: Techniques for Analyzing Industries and Competitors. New York: Free Press.

Porter, M. E. (1981). The Contributions of Industrial Organization to Strategic Management. The Academy of Management Review, 6(4), 609-620. Retrieved from http://www.jstor.org/stable/257639

Porter, M. E. (1985). Competitive Advantage: Creating and Sustaining Superior Performance. New York: Free Press.

Prahalad, C. K., \& Hamel, G. (1990). The Core Competence of the Corporation. Harvard Business Review, 68(3), 79-91. Retrieved from https://www.profrandes. com.br/userfiles/37e2f78e93b640608ec17b8de1b6d4b5.pdf

Rađenović, T., \& Krstić, B. (2017a). Intellectual Capital as the Source of Competitive Advantage - The Resource-Based View. Facta Universitatis Series: Economics and Organization, 14(2), 127-137. doi:10.22190/FUEO1702127R

Rađenović, T., \& Krstić, B. (2017b). The Microeconomic Perspectives of Intellectual Capital Measurement. Facta Universitatis, Series: Economics and Organization, 14(3), 189-202. doi:10.22190/FUEO1703189R

Robinson, J. (1933). The Economics of Imperfect Competition. London: MacMillan Press.

Romer, P. M. (1990). Endogenous Technological Change. Journal of Political Economy, 98(5), 71-102.

Roos, G., \& Roos, J. (1997). Measuring Your Company’s Intellectual Performance. Long Range Planning, 30(3), 413-426. doi:10.1016/S0024-6301(97)90260-0

Rubin, P. H. (1973). The Expansion of Firms. Journal of Political Economy, 81(4), 936-949. Retrieved from http://www.jstor.org/stable/1831135

Rumelt, R. P. (1997). Towards a Strategic Theory of the Firm. In N. J. Foss, Resources, Firms, and Strategies: A Reader in the Resource-Based Perspective (pp. 131145). Oxford: Oxford University Press.

Scherer, F. M. (1970). Industrial Market Structure and Economic Performance. Chicago: Rand McNally College Publishing Co.

Schultz, T. W. (1961). Investment in Human Capital. The American Economic Review, 51(1), 1-17. 
Schumpeter, J. (1934). The Theory of Economic Development. Cambridge, MA: Harvard University Press.

Spanos, Y. E., \& Lioukas, S. (2001). An Examination into the Causal Logic of Rent Generation: Contrasting Porter's Competitive Strategy Framework and the Resource-Based Perspective. Strategic Management Journal, 22(10), 907-934. doi:10.1002/smj.174

Spender, J.-C. (1996). Making Knowledge the Basis of a Dynamic Theory of the Firm. Strategic Management Journal, 17(S2), 45-62. doi:10.1002/smj.4250171106

Stewart, T. A. (1997). Intellectual Capital: The New Wealth of Organizations. New York: Doubleday/Currency.

Stinchcombe, A. L. (1965). Social Structure and Organizations. In J. G. March (Ed.), Handbook of Organizations (pp. 142-193). Chicago: Rand McNally \& Company.

Sveiby, K.-E. (1997). Intangible Assets Monitor. Journal of Human Resource Costing and Accounting, 2(1), 73-97. doi:10.1108/eb029036

Sweetland, S. R. (1996). Human Capital Theory: Foundations of a Field of Inquiry. Review of Educational Research, 66(3), 341-359. Retrieved from http://www. jstor.org/stable/1170527

Taylor, F. (1911). The Principles of Scientific Management. New York: Harper \& Brothers.

Teece, D. J. (1986). Profiting from Technological Innovation: Implications for Integration, Colaboration, Licensing and Public Policy. Research Policy, 15(April), 285-305.

Teece, D. J. (2000). Managing Intelectual Capital: Organizational, Strategic and Policy Dimensions. Oxford: Oxford University Press.

Teece, D. J., Pisano, G., \& Shuen, A. (1997). Dynamic Capabilities and Strategic Management. Strategic Management Journal, 18(7), 509-533. doi:10.1002/ (SICI)1097-0266(199708)18:7<509::AID-SMJ882>3.0.CO;2-Z

Viedma Marti, J. M. (2007). In Search of an Intellectual Capital Comprehensive Theory. The Electronic Journal of Knowledge Management, 5(2), 245-256.

Viedma Marti, J. M., \& Cabrita, M. R. (2012). Entrepreneurial Excellence in the Knowledge Economy: Intellectual Capital Benchmarking Systems. Basingstoke: Palgrave Macmillan.

Walsh, J. P., \& Ungson, G. R. (1991). Organizational Memory. Academy of Management Review, 16(1), 57-91. Retrieved from http://www.jstor.org/stable/258607

Wernerfelt, B. (1984). A Resource-Based View of the Firm. Strategic Management Journal, 5(2), 171-180. Retrieved from http://www.jstor.org/stable/2486175

Zander, U., \& Kogut, B. (1995). Knowledge and the Speed of the Transfer and Imitation of Organizational Capabilities: An Empirical Test. Organization Science, 6(1), 76-92. Retrieved from http://www.jstor.org/stable/2635241

Zott, C. (2003). Dynamic Capabilities and the Emergence of Intraindustry Differential Firm Performance: Insights from a Simulation Study. Strategic Management Journal, 24(2), 97-125. doi:10.1002/smj.288 